\title{
Máscaras e (des)mistificações: estratégias para a literatura contemporânea
}

\author{
Biagio D'ANGELO \\ (Pontifícia Universidade Católica de São Paulo)
}

processo da escrita, afirma Maurice Blanchot, começa com o olhar de Orfeu. O reconhecimento da figura poética de Orfeu como patriarca da atividade da poiesis parece metamorfosear-se nas culturas brasileiras e portuguesas da contemporaneidade numa decisão de "contar a morte". Trata-se de um relato que repropõe a figuração do mito às avessas: se Orfeu é o paladino e o arquétipo mitológico do poeta-cantor, que, desde a floresta dos mitos, vive (de) um discurso privilegiado, ao mesmo tempo, ele é cantor de morte e da dissolvência da realidade. "A obra é Orfeu - escreve Blanchot - mas é também a potência adversa que a rasga e que reparte Orfeu. [...] A obra só é obra se é a unidade dilacerada" (BLANCHOT, 1987: 227). A literatura, cujo tecido parece declarar o espaço mortífero como lugar de reflexão escritural, apresenta-se, também, como possibilidade misteriosa de vida contínua e renovada do ponto de vista epistemológico.

Uma capa, que lembra a cara obscura e misteriosa da lua, símbolo de apaziguamento e de trauma sofrido, de reflexão silenciosa e de questionamento aos deuses, inspira as páginas penetrantes dos ensaios que compõem a coletânea De Orfeu e de Perséfone: morte e literatura. São Paulo:Ateliê Editorial/Belo Horizonte:PUC Minas, 2008, organizada por Lélia Parreira Duarte.

O texto de Márcio Seligmann-Silva que, nas orelhas do livro, introduz o leitor à proposta do Grupo de Pesquisa sobre as figurações da morte nas literaturas contemporâneas brasileira e portuguesa, elucida as significações semânticas e, portanto, as interpretações possíveis do nome "Perséfone":

derivado, por alguns autores, de pherein phonon, "trazer" ou "causar a morte". Mas existe outra aproximação semântica possível: em etrusco, phersu significa a 
pessoa que porta uma máscara (originalmente em rituais fúnebres). Daí vem o termo latino persona, ou seja, o personagem dramático com sua máscara.

E a máscara, elemento também mitológico por excelência, revela, uma e outra vez, seu paradoxo: ela é a testemunha especial da falência da História, isto é, testemunha de uma impossibilidade a dizer e a narrar que se consolida no espaço do discurso literário. Esconde, mas revela, ao mesmo tempo.

Os ritos de morte e renascença, de amor e morte, de opostos que nunca se apresentam como completamente opostos, desde sempre interessam ao fazer literário. A estética se move, com efeito, a partir da fundação da imbricação múltipla e produtiva desses pólos antropológicos. A literatura propõe, nesse sentido, uma busca incansável de sentido, uma irradiação de conhecimento, até quando o conhecimento ou o sentido revela "apenas" uma linguagem mortífera. O que pode sustentar o gesto literário senão "saber de não saber"? Em um artigo sobre a "insustentável leveza do mito", Paola Mildonian aponta que "no grande romance pós-colonial [...] o mito volta a encenar a tragédia da ignorância do homem, Édipo que não sabe que nada sabe". O mito e a máscara são fortemente entrelaçados. Os japoneses sabem muito bem a força enigmática, porosa e ambígua da máscara (Yukio Mishima, particularmente). A máscara serve para desvendar o que está escondido na face da realidade. Ela sublinha que o Parecer tem um valor emblemático e sua ligação com o Ser é um caminho para suspender os estereótipos e problematizar as questões que vinculam o sujeito com o mundo. A morte se disfarça (se mascara) na literatura por meio de temáticas, tópicos, memórias, rasgaduras, feridas, buracos, dilacerações violentas e sangues que fazem o presente da atividade estética e dilatam o questionamento sobre a existência. Os textos então resultantes se elaboram mais na dimensão performática da escrita que no seu apelo pedagógico. Mais que ensinar o vazio e a não-conclusão, eles desvendam o mecanismo da linguagem como lugar de morte e de vitória sobre a morte. Autores como António Lobo Antunes, Guimarães Rosa, Maria Judite de Carvalho, Ruy Belo, Augusto de Campos, entre outros, revelam-se extraordinários emblemas de uma realidade que, por falta de sentido, está se desvanecendo. Porém, apesar da morte e da desolação, Orfeu entra em socorro e a Perséfone que é a literatura renasce, como a fênix, determinando textos que gritam, mais uma vez, a vivacidade da escrita e as possibilidades fecundas 
de pensarmos, por meio das palavras, nas angústias que povoam nossos dias. Autores como Mônica Figueiredo, Teresa Cristina Cerdeira, Clara Rowland, Cid Ottoni Bylaardt, e a própria organizadora, Lélia Parreira Duarte, entre muitos outros, corroboram a escrita pluriforme de escritores e poetas portugueses e brasileiros por meio das intuições críticas de pensadores, que dedicaram à morte e aos interstícios entre a vida da escrita e o ditado da morte, reflexões questionadoras. Os autores se relacionam por não apresentarem verdades estabelecidas e dogmáticas, vítimas da angústia existencial e, ao mesmo tempo, da melancolia que procede da impossibilidade de uma resposta ao desejo, sempre insatisfeito, de felicidade. Os textos apresentados revelam, ao contrário, “a inutilidade de qualquer palavra ou gesto” (p. 13), pois neles, escreve Lélia Duarte com uma sugestiva imagem poética, "o eu que fala - que é diferente do eu que pensa "é como um ventríloquo ou como uma máscara que murmura - é um outro” (p. 13). Agamben, Blanchot, Hannah Arendt, para citar apenas poucos nomes, configuram o tecido das significações hermenêuticas propostas pelos pesquisadores. A literatura proposta, portanto, é voluntariamente ambígua - como, aliás, toda boa literatura. Esses textos - como se pode ler numa introdução muito esclarecedora - "não usam uma linguagem transparente que promete a paz, porque a literatura que se estuda nesta pesquisa é a que cria o objeto, sem representar ou imitar algo que existe no mundo" (p. 13). A organizadora do volume adverte que "estudar essas obras literárias é, portanto, uma forma de melhor sondar e compreender os saberes de uma escrita que privilegia as questões da textualidade e da leitura, pois trata-se de textos que se ironizam a si mesmos, confessando-se artefato, artifício, elaboração, jogo, arte, revelando consciência de seu caráter de linguagem, exibição do vazio e da falta que caracterizam o sujeito" (p. 12). Passam em resenha, assim, autores como Maria Judite de Carvalho, à qual são dedicados dois ensaios admiráveis, Ruy Belo e António Lobo Antunes, que compõem apenas uma mínima parte do rico catálogo de narradores e poetas que, conforme as palavras de Maurice Blanchot, "escreve(m) para morrer e [...] recebe $(\mathrm{m})$ o seu poder de escrever de uma relação antecipada com a morte" (BLANCHOT, 1987: 90). Se Perséfone representa, alegoricamente, a máscara de uma escrita errática, uma distopia, isto é, uma distorção de um modelo apaziguador e, talvez, perfeito de literatura, Orfeu fica a simbolizar a obra literária como espaço de fragilidade e insatisfação. Com efeito, quando 
Orfeu poderá se dizer completo, senão no gesto de comunhão do produto da escrita, "com-união" do Poeta e do Texto?

\section{Referência Bibliográfica}

BLANCHOT, M. O espaço literário. Rio de Janeiro: Rocco, 1987. 